\title{
Extracellular Calcium and Magnesium in Preeclampsia and Eclampsia
}

*Idogun E.S, ** Imarengiaye C.O, * Momob S.M.

\begin{abstract}
The cause of preeclampsia remains unknown and calcium and magnesium supplement are being suggested as means of prevention. The objective of this study was to assess magnesium and calcium in the plasma and cerebrospinal fluid of Nigerian women with preeclampsia and eclampsia.

Setting was University of Benin Teaching Hospital, in Nigeria. It was a cross-sectional study comprising of eleven patients and twenty-three controls. The mean, standard deviation and Standard Error of Mean (SEM) were calculated. Student ' $t$ ' test method was applied.

Plasma calcium was significantly lower in patients than controls (9.2 $\pm 1.02 \mathrm{Vs} 9.98 \pm 0.87 \mathrm{mg} / \mathrm{dl}, \mathrm{P} 0.043)$ " $\mathrm{t}$ " test. The CSF calcium and magnesium levels were lower in patients than controls, $(5.66 \pm 1.22$ vs $6.67 \pm 1.15 \mathrm{mg} /$ $\mathrm{dl}, \mathrm{P} 0.043$ and $1.75 \pm 0.56$ vs $1.91 \pm 0.19 \mathrm{mg} / \mathrm{dl}, \mathrm{P} 0 .<0.0001)$ respectively.

There is extracellular calcium and magnesium reduction in patients with preeclampsia and eclampsia. This reduction may have a cause and effect relationship with these disorders. (AfrJ Reprod Health 2007; 11[2]:80-85).
\end{abstract}

\section{RÉSumé}

Le calcium extracellulaire et le magnésium au cours de la rééclampsie et l'éclampsie On ne connait pas toujours la cause de l'éclampsie et le calcium et le supplément de magnésium ont été suggérés comme moyens de prévention. Cette étude a pour objectif d'évaluer le magnésium et le calcium dans le plasma et dans le liquide céphalo - rachidien chez les femmes nigérianes qui souffrent de la prééclampsie et de l'éclampsie. Le cadre était le Centre Hospitalier Universitaire (UBTH) à Benin, au Nigéria. Il s'agissait d'une étude transversale qui comprenait onze patientes et vingt-trois témoins. L'écart type de la moyenne et l'Erreur Type de la Moyenne (ETM) ont été calculés. La méthode de test de ' $t$ ' de l'étudiant a été appliqué. La calcium du plasma était moins élevé chez les patientes que chez les témoins $(9,2 \pm, 02 \mathrm{Vs} 9,98 \pm 0,87 \mathrm{mg} / \mathrm{dl})$ le test de "t". Les niveaux du calcium et du magnésium du liquide céphalo-rachidien (LLR) étaient moins élevés chez les patientes que chez les témoins (5,66 $\pm 1,22$ Vs $6,67 \pm 1,15 \mathrm{mg} / \mathrm{dl}, \mathrm{P} 0,043$ et $1,75 \pm 0,56 \mathrm{Vs} 1,91 \pm 0,19 \mathrm{mg} / \mathrm{dl}, \mathrm{P} 0,<0,0001)$ respectivement. Il y a une réduction du calcium extracellulaire chez les patientes souffrant de la prééclampsie et de l'éclampsie. Cette réduction pourrait avoir un rapport de cause et d'effect avec ces troubles. (Rev Afr Santé Reprod 2007;11[2]:80-85).

KeY Words: Pre-eclampsia, Eclampsia, Calcium, Magnesium.

*Idogun E.S, ** Imarengiaye C.O, * Momoh S.M.

*Department of Chemical Pathology, UBTH, Benin Benin-city. Nigeria.

**Department of Anaesthesiology, College of Medicine, Benin Benin-city, Nigeria.

Correspondence to: Dr. Idogun E.S., Department of Chemical Pathology, University of Benin Teaching Hospital P.M.B 1111, Benin City, Nigeria.E-mail:Sylvesteridogun@,Yahoo.co.uk. 


\section{Introduction}

Preeclampsia is defined as the triad of hypertension, proteinuria and oedema occurring after 20 weeks gestation in a previously normo-tensive woman ${ }^{1}$ It is specific to human pregnancy and complicate $6-8 \%$ of gestation after week $20^{1}$ Preeclampsia is still one of the leading causes of maternal and fetal morbidity and mortality. ${ }^{2}$

Despite active research for many years, the etiology of this disorder remains unknown ${ }^{3}$, although contributory factors include, obesity, diabetes, calcium deficiency ${ }^{4,5}$, older maternal age and job stress ${ }^{6,7}$. Environmental and nutritional factors may therefore play a role in the aetiology of preeclampsia. Therefore there is a need to explore these factors.

The management of preeclampsia includes medications to reduce high blood pressure, strict bed rest, maintenance of normal salt intake, possibly hospitalization and induced delivery or caesarean section. Despite the improved health care world wide, preeclampsia and eclampsia continue to take a great toll on the life of pregnant women especially in rural Nigerian communities where obstetric interventions may be lacking or inadequate.

Research is focusing on prevention ${ }^{8,9}$ of preeclampsia rather than treatment. Among the advocated modalities of prevention is calcium and magnesium supplementation ${ }^{10,11}$. This is based on the physiology of these intracellular ions in cellular and neuronal metabolism and functions.

The objective of this study was to assess magnesium and calcium levels in the plasma and cerebrospinal fluid of Nigerian women with preeclampsia and eclampsia, with the purpose of establishing the extracellular status of these ions. Magnesium and calcium ions have been implicated in seizure disorders, which often complicate preeclampsia. It is therefore imperative to evaluate the levels of these ions in our women, with the aim of providing preliminary data that could be useful in the management of preeclampsia and eclampsia using calcium and magnesium supplementation.

African Journal of Reproductive Health Vol. 11 No.2 August, 2007

\section{Methodology}

Patients:

It was a cross-sectional study, comprising of eleven patients and twenty-three controls that were randomly selected from among hospital attendees. The patients were selected based on pre-set criteria by the researchers. The inclusion criteria for the patients were: age, $16-45$ years, pregnancy in the third trimester diagnosed (preeclampsia), as defined in accordance with (U.S) National High Blood Pressure Education Program working group ${ }^{12}$ with or without eclampsia, going for caesarean section. Patients on magnesium sulphate and calcium lactate drugs were excluded from the study.

The controls were selected from pregnant normotensive women also in the third trimester, undergoing caesarean section but not diagnosed as having preeclampsia or eclampsia, in the same age range. Excluded from the study were are patients with medical complications such as diabetes mellitus, renal failure, heart failure or ischaemic heart diseases (diseases that alters vascular response). Patients and controls were sampled with a well-designed questionnaire, administered by the researchers.

Ethical consideration: Ethical approval was obtained from the hospital research ethical committee. All patients and controls gave their approval after due explanation by the researchers.

Laboratory methods: Blood and CSF collections were made in the operating theatre during the anaesthetic procedure for caesarean section. $5 \mathrm{mls}$ of venous blood was collected from the cubital veins after the routine aseptic procedures. The blood was dispensed into lithium heparin specimen bottles and was separated after centrifugation for $5-10$ minutes at $3000 \mathrm{rpm}$. The plasma were harvested with clean Pasteur pipettes and immediately stored frozen at $-20^{\circ} \mathrm{C}$, until analysis was carried out for Calcium, magnesium and Electrolyte and Urea estimations. 
The cerebrospinal fluid was taken during lumber puncture procedure for spinal anaesthesia by the anaesthetist. $2 \mathrm{mls}$ of cerebrospinal fluid was obtained and dispensed as follows: one half into lithium heparin bottle for CSF calcium and magnesium, estimations while the other half was put into fluoride oxalate bottle for CSF glucose estimation. The CSF samples were not stored as the analyses were done on the same day.

\section{Laboratory Analytical Procedure}

All assay methods were well-established methods. Plasma and CSF magnesium levels were assayed using a spectrophotometric manual method using xylidyl blue as the colour indicator ${ }^{13}$. The kit is manufactured by DIALAB. Plasma and CSF calcium was also by spectrophotometric manual method, using O-cresolphthalein - complexone as the colour indicator ${ }^{14}$. The calcium kits are also manufactured by DIALAB.

\section{Statistical Analysis}

All data were analyzed using computer with Instat graphpad soft ware V2.05a. The mean, standard deviation and SEM were calculated. Student ' $\mathrm{t}$ ' test and correlation statistical methods were applied. The level of significance was set at $\mathrm{p} \leq$ 0.05 .

\section{Results}

Eleven patients and 23 controls were studied Table 1 . The mean age of the patients was $32 \pm$ 5.72 years, and that of the controls was $33 \pm$ 5.72 years, $\mathrm{P} 0.027$ (t-test), $20 \%(\mathrm{n}=7)$ of the patients were booked compared to $44 \%(n=15)$ of the controls, and $11.8 \%(\mathrm{n}=4)$ of the patients were unbooked compared to $23.5 \%(n=8)$ of the control. Most of the patients and controls were of parity between 1 and 2 .

The mean systolic blood pressure was 165.45 $\pm 30.45 \mathrm{mmHg}$ for patients and $112.61 \pm 10.10$ $\mathrm{mmHg}$ for controls, $\mathrm{P}<0.0001$ (t-test), The mean diastolic blood pressure for patients was 108.18 $\pm 20.89 \mathrm{mmHg}$ and $68.68 \pm 6.26 \mathrm{mmHg}$ for controls, $\mathrm{P}<0.0001$ (t-test).

Table 2. Plasma calcium was significantly higher in controls than patients $(9.98 \pm 0.87$ vs $9.2 \pm 1.02 \mathrm{mg} / \mathrm{dl}, \mathrm{P} 0.043$ (t-test). There was no

Table 1 Some Demographic characteristics of patients and controls

\begin{tabular}{|c|c|c|c|c|}
\hline & \multicolumn{2}{|c|}{ Patients $(\mathrm{n}=11)$} & \multicolumn{2}{|c|}{ Controls $(n=23)$} \\
\hline Age (years) & \multicolumn{2}{|c|}{$32 \pm 5.27$} & \multicolumn{2}{|l|}{$33 \pm 5.72$} \\
\hline Booking status & Number (n) & $(\%)$ & Number (n) & $(\%)$ \\
\hline Booked & 7 & (20.6) & 15 & (44.1) \\
\hline Unbooked & 4 & $(11.8)$ & 8 & (23.5) \\
\hline \multicolumn{5}{|l|}{ Parity } \\
\hline Para 0 & 3 & (8.8) & 7 & (20.6) \\
\hline Para 1 & 4 & $(1.2)$ & 9 & (26.8) \\
\hline Para 2 & 2 & $(0.6)$ & 4 & $(1.2)$ \\
\hline Para 3 & 1 & $(0.3)$ & 1 & $(0.3)$ \\
\hline Para 4 & 0 & $(0)$ & 1 & $(0.3)$ \\
\hline Above para 4 & 1 & $(0.3)$ & 1 & $(0.3)$ \\
\hline \multicolumn{5}{|l|}{ Preeclampsia/eclampsia } \\
\hline Preeclampsia & 8 & $(72.7)$ & 0 & (0) \\
\hline Eclampsia & 3 & $(27.3)$ & 0 & (0) \\
\hline Blood pressure & \multirow{2}{*}{\multicolumn{2}{|c|}{$165.45 \pm 30.45$}} & & \\
\hline Systolic (mmHg) & & & $112.61 \pm 10.10$ & $\mathrm{p}<0.0001$ \\
\hline Diastolic $(\mathrm{mmHg})$ & \multicolumn{2}{|c|}{$108.18 \pm 20.89$} & $68.69 \pm 6.26$ & $\mathrm{p}<0.0001$ \\
\hline
\end{tabular}

African Journal of Reproductive Health Vol. 11 No.2 Angust 2007 
significant difference between the plasma magnesium of the patients and controls $1.5 \pm$ 0.28 vs $1.55 \pm 0.32 \mathrm{mg} / \mathrm{dl}, \mathrm{P} \quad 0.28$ (t-test). The mean CSF calcium of patients $5.66 \pm 1.22 \mathrm{mg} /$ $\mathrm{dl}$ was significantly lower than the controls 6.87 $\pm 1.15 \mathrm{mg} / \mathrm{dl}$, P 0.043 (t-test). So also is the CSF magnesium lower in patients than controls 1.75 \pm 0.56 vs $1.91 \pm 0.19 \mathrm{mg} / \mathrm{dl}, \mathrm{P}<0.0001$ (t-test). Serum calcium : serum magnesium ratio was lower in patients than controls 5.9 vs 1.6, so also was the serum calcium : CSF calcium ratio 1.4 vs 1.6. The serum magnesium: CSF magnesium ratio was also lower in patients than controls, 1.2 vs 1.3 respectively.

\section{Discussion}

Calcium and magnesium are two intracellular ions that are very important for cellular metabolism such as muscle contractility, secretions, neuronal activity as well as cellular death ${ }^{15}$.

Our result shows that there are reduced calcium and magnesium levels in patients with preeclampsia. This is consistent with findings in other studies ${ }^{5,10,11}$. While the cause of preeclampsia remains elusive to scientific knowledge, magnesium and calcium deficiencies are thought to be implicated ${ }^{4,10,16}$. Studies from the early 1950s first elucidated the nature of the effects of calcium and magnesium ions at the neuromuscular junctions ${ }^{11}$. Magnesium competes for a prejunctional site with calcium ions ${ }^{11}$. The ions competed with each other, high magnesium concentrations inhibit the release of acetylcholine (Ach) and high calcium concentration increases release of Ach from pre-synaptic nerve terminal ${ }^{11}$.

During cellular injury and cellular death, there is influx of calcium ions into the cell leading to increased intracellular calcium ions and loss of calcium homeostasis ${ }^{11}$. This mechanism precedes cell death and is also seen in reperfusion injuries ${ }^{15}$

We also know that there is vasospasm, ischaemia as well as cellular hypoxia in severe preeclampsia and eclampsia which may cause reperfusion injury (reversible cell injury) following treatment. Since magnesium physiologically is antagonist to calcium ${ }^{11}$, it follows that in an attempt to mitigate cellular injury by calcium; there will also be influx of magnesium during reperfusion. This could explain why both calcium and magnesium were reduced in the blood and CSF of our patients. This hypothesis will need to be tested by well-controlled experimental studies.

It has been estimated that magnesium intake has declined by more than half during this century $^{11}$, because of a reduction in magnesium with the ecosystem resulting in reduced magnesium content of food items. The magnesium and calcium content of food is further compromised with overcooking, processing and reprocessing of food products.

The consequences of low magnesium may lead to a reduction in cerebral blood flow, cerebral

Table 2: Extracellular concentration (mean) of calcium and magnesium in patients and controls

\begin{tabular}{lcccc}
\hline Parameter & Patients $(\mathbf{n}=\mathbf{1 1})$ & Controls $\mathbf{( n = 2 3 )}$ & P-value & S/NS \\
\hline Serum calcium $(\mathrm{mg} / \mathrm{dl})$ & $9.2 \pm 1.02$ & $9.8 \pm 0.87$ & 0.043 & $\mathrm{~S}$ \\
Serum magnesium $(\mathrm{mg} / \mathrm{dl})$ & $1.5 \pm 0.28$ & $1.55 \pm 0.32$ & 0.278 & $\mathrm{NS}$ \\
CSF calcium $(\mathrm{mg} / \mathrm{dl})$ & $5.66 \pm 1.22$ & $6.87 \pm 1.15$ & 0.043 & $\mathrm{~S}$ \\
CSF magnesium $(\mathrm{mg} / \mathrm{dl})$ & $1.75 \pm 0.56$ & $1.91 \pm 0.19$ & $<0.0001$ & $\mathrm{~S}$ \\
Serum Ca:Mg ratio & 5.9 & 6.1 & - & - \\
Serum Ca:CSF Ca ratio & 1.4 & 1.6 & - & - \\
Serum Mg:CSF Mg ratio & 1.2 & 1.3 & - & - \\
\hline $\mathbf{n}=$ number & & & & \\
$\mathbf{S}=$ Significant & & & & \\
NS = Not Significant & & & & \\
African Journal of Reproductive Health & Vol. 11 No.2 August, 2007 & & &
\end{tabular}


vasospasm and increase in neuronal burst. Macdonald et $\mathrm{al}^{17}$ have shown experimentally that magnesium has a vasoprotective effect. And this explains the use of magnesium sulphate as a neuroprotectant and antivasospastic agent. Magnesium $\left(\mathrm{mg}^{++}\right)$may increase cerebral blood flow and reduce the contraction of cerebral arteries caused by various stimuli ${ }^{17}$. The clinical implication of low magnesium seen in our patients may be vascular contractility, low cerebral blood flow and a tendency to eclamptic fits. Physicians now agree that the medication for seizures in preeclampsia is magnesium sulfate ${ }^{18}$. The systemic effects of magnesium include vasodilatation and an increase in blood flow, these prevent eclampsia by selectively dilating the cerebral vasculature and relieving the cerebral vasospasm associated with preeclampsia. In the eclamptic patient, it will prevent recurrent seizures which is beneficial in reducing the mortality and morbidity in both mother and fetus ${ }^{18}$.

Calcium and magnesium ratio are important in excitability and burst firing of neuronal cells ${ }^{19}$. We found low extracellular fluid concentrations of calcium and magnesium as well as reduced ratio of calcium and magnesium in our study. These extracellular changes could explain why some of our patients suffered convulsion (eclampsia) since small decreases in extracellular calcium and/or magnesium will lead to increased excitability and burst firing, which alter physiologic and pathophysiologic processes such as enhancing long-term potentiation, pain transmission, epileptogenesis, and neuronal damage ${ }^{19}$. Increase in extracellular calcium and magnesium would have the opposite effect on these processes. According to Wang and et al, these effects of extracellular divalent ions on burst firing may explain some of the pathophysiologic effects of hypocalcaemia and hypomagnesaemia ${ }^{19}$. Some other studies have demonstrated that magnesium has neuroprotective effects as well as protect against vasospasm ${ }^{20}$. The consequences of these deficiencies may therefore be responsible for the clinical manifestations that are observed in this disease, since both ions are important in cellular and neuronal metabolism as well as cell membrane stability ${ }^{11}$.

\section{Conclusion}

There are reduced extracellular calcium and magnesium levels in patients with preeclampsia and eclampsia. These lower levels may have a cause and effect relationship with these disorders, and these data may therefore be found useful when considering interventional management of preeclampsia and eclampsia using magnesium and calcium supplementation.

\section{Acknowledgement}

We want to thank the secretariat staff of chemical pathology department for typing this manuscript. And we also thank all the resident doctors in the same department and the department of Anaesthesiology for their co-operation in sample collection.

\section{REFERENCES}

1. Redman CWG, Jefferis M. Revised definition of preelcampsia. Lancet 1988; 1:809-12.

2. Pridjan G. PuschettJB. Preeclampsia. Part 1 clinical and pathophysiologic considerations. Obstet Gynecol Surv 2002; 57: 598 - 618.

3. Onder Celik, Seyma Hascalik, Yusuf Turkoz, Mehmet Hascalik, Remzi Gokdeniz. Cerebrospinal fluix nitric oxide level changes in preeclampsia. European Journal of obstetrics and Gynaecology and Reproductive Biology 2003; 111 : 141 - 145.

4. Sibai B. Prevention of preeclampsia: a big disappointment. Am J Obstet Gynecol 1998;179:1275-8.

5. Hojo M, August P. Calcium Metabolism in Preeclampsia: Supplementation may help. Medscape Womens Health 1997;2:5.

6. Marcoux S, Berube S, Brisson C, Mondor M. Job strain and pregnancy-induced hypertension. Epidemiology 1999; 10:376-82.

7. Wergeland E, Strand K. Work place control and pregnancy health in a population-based sample of

African Journal of Reproductive Health Vol. 11 No.2 August 2007 
employed women in Norway. Scand J work Environ Health 1998;24:206-12.

8. Salvig JD, Olsen SF, Secher NJ. Effects of fish oil supplementation in late pregnancy on blood pressure: a randomized controlled trial. BrJ Obstet Gynaecol1996;103:529-33.

9. Schiff E, Friedman SA, Stampfer M. Dietary consumptions and plasma concentrations of vitamin E in pregnancies complicated by preeclampsia. Am J Obstet Gynaecol 1996;175:1024-8.

10. Sibai MB, Villar MA, Bray E. Magnesium supplementation during pregnancy: a double-blind study. BrJ Obstet Gynaecol 1988;950:120-5.

11. Fawett W.J, Haxby E.J, Male D.A. Magnesium: physiology and pharmacology. BrJ Anaesth 1999;83: 302-20.

12. National High Blood Pressure Education Program: Working Group report on primary prevention of hypertension. Arch Intern Med 1993; 153: 186 208.

13. David B.E, Robert K.R. Mineral and Bone metabolism (magnesium) in: Tietz Text book of clinical Chemistry $3^{\text {rd }}$ Ed. Carl A. Burtis, Edward R. Ashiroid; W.B. Sanders Company, Philadelphia 1999: $1408-1410$.

14. David B.E, Robert KR. Mineral and Bone metabolism (magnesium) in: Tietz Text book of clinical Chemistry $3^{\text {rd }}$ Ed. Carl A. Burtis, Edward
R. Ashiroid; W.B. Sanders Company, Philadelphia 1999: 1398 - 1399 .

15. Vinay Kumar. Cellular adaptation, cell injury, and cell death in: Robins and Contran pathologic Basis of Disease. $7^{\text {th }}$ Ed. Vinay Kumar, Ardul, K. Abbas, Nelson Fausto. Elsevier Saunders, Philadelphia, 1999; pg 3- 46.

16. Wynn A, Wynn M. Magnesium and other nutrient deficiencies as possible causes of hypertension and low birth weight. Nutr Health 1988;6:69-88.

17. Macdonald RL, Curry DJ, Aihara Y, Zhang ZD, Jahromi BS, Yassari R. Magnesium and experimental vasospasm. J Neurosurg. 2004 Jan; 100(1): $106-10$.

18. Shahnaz A, Payam K. Fatemeh G, Anahita M. Serum magnesium and calcium ions in patients with severe pre-eclampsia/eclampsia undergoing magnesium sulfate therapy. Med Sci Monit, 2007, 13(4): $191-194$.

19. Wang T, Wang J, Cottrell JE, Kass IS. Small physiologic changes in calcium and magnesium alter excitability and burst firing of CIA pyramidal cells in rat hippocampal slices. J Neurosurg Anesthesiol. 2004 July; 16(3): $201-9$.

20. Pyne GJ, Cadoux-Hudson TA, Clark JF. Magnesium protection against invitro cerebral vasospasm after subarachnoid haemorrhage. Br.J Neurosurg. 2001/Oct. 15(5): 409 - 15. 